\title{
ЗАПИСКА ПО ВОПРОСУ О МЕРАХ К ПРЕСЕЧЕНИЮ РАСПРОСТРАНЕНИЯ НЕДОЗВОЛЕННОГО ОБУЧЕНИЯ В СЕВЕРО-ЗАПАДНОМ КРАЕ
}

\author{
Вступна стаття
}

У загальному процесі соціально-економічного і культурного розвитку у XIX - на початку XX ст. з-поміж інших значного поширення набули приватні навчальні заклади, представлені усіма типами освіти - від дошкільної до вищої. Це були навчальні та навчально-виховні заклади, заснування яких ініціювала не держава, а окремі особи чи інституиії. Проте держава залишала за собою право регулювати та контролювати їх діяльність.

Прослідкувати як ідеологічні та політичні чинники впливали на діяльність та поширення державних та приватних навчальних закладів дає можливість рукописна «Записка по вопросу о мерах к пресечению распространения недозволенного обучения В северо-западном крае».

Праця заслуговуе на увагу, оскільки написана сучасником тогочасних подій. Він описуе реальний стан речей $b$ освітній галузі крізь призму власного сприйняттяя. Опираючись на Власні спостереження та аналіз законодавчих документів автор не лище здійсни короткий історичний опис становлення системи освіти $b$ північно-західній частині Російської імперії, а й окреслив завдання уряду, зумовлені впливом політичних подій, щодо поширення навчальних закладів.

Особлива увага автором приділена питанню викладання польської мови в закладах різного типу та участі осіб польського походження $\mathrm{b}$ діяльності навчальних закладів. Автор також розкриває взаємовплив освіти та політичних подій, формування свідомості молоді, прослідковує державну політику щодо насадження російської культури в регіоні. Аналіз публікації дає змогу більш иілісно уявити процеси, що відбувалися $b$ системі освіти у той час, і який вплив вони мали на шкільну приватну освіту.

Із метою ведення до наукового обігу пропонуемо архівний матеріал Інституту рукопису Національної бібліотеки України імені В. І. Вернадського «Записка по вопросу о мерах к пресечению распространения недозВоленного обучения В северо-западном крае. Составлена В ответ на возражения Г. Управляющего Мин-ством Юстиции, изложенные в отзыве в Мин-ство Нар. Просв. От 14 июня 1886 года, за № 47296». Текст адаптований до читання, проте збережено усі лексичні та фразеологічні особливості. Сподіваємося, щцо поданий нижче матеріал, приверне увагу дослідників історії педагогіки та всіх, хто хоче розширити знання з історії становлення системи освіти, зокрема приватної.

Підготовка до публікації і вступна стаття Світлани Роєнко

Начало систематических мероприятий правительства по отношению к народному образованию в С. 3. крае относится ко времени первого польского мятежа, когда политическое положение края вызвало закрытие Виленского Университета и приостановление почти всех училищ в губерниях, возвращенных от Польши. Приняв такую решительную репрессивную меру по отношению к существовавшим учебным заведениям, которые, как оказалось, послужили, в руках политиков, главным и верным средством подготовления политических событий 1830 года, правительство решило восстановить общественное образование в крае и вести оное на будущее время на иных, русских началах, по строго определенному плану [арк. 21-22].
В таком смысле и состоялось Высочайшее повеление в первый пос. год по усмирении польского мятежа 1830 г., именно в 4 день апреля 1831 г. Государь Император Высочайше повелел соизволить, чтобы Министерство Нар. Просв. и в особенности Попечитель Белорусского Учеб. Окр., направляя публичное воспитание юношества в С. 3. крае, имел поточною своею целью «сближения тамошних жителей с природными русскими» [арк. 22].

Стремясь к воспитанию юношества на русских началах, правительство прежде всего обратило свое внимание на низшие сословия. Воспитание юношества, принадлежавшего к этим сословиям, сосредоточивалось тогда в приходских училищах, которые находились исключительно 
в руках римско-католического духовенства. Обучение в этих училищах производилось на польском языке и вообще р.к. духовенство, при помощи руководимых им приходских училищ, оказывало весьма вредное влияние на коренное население края, воспитывая юношество в духе религиозной нетерпимости и в разных заблуждениях относительно исторического прошлого края и тем поддерживая в населения религиозное и политическое отчуждение от России. Необходимо было изъять прих. училища из рук р.к. духовенства и, преобразовать их в светские училища, подчиненные прямому и непосредственному влиянию учебного начальства, ввести в них преподавание всех вообще наук на русском языке и вообще учить их на началах русских, чтобы, при помощи такого рода училищ сблизить коренное население края с природнорусскими [арк. 22-23].

Преобразование р.к. приходских училищ в светские училища, с введением преподавания в них на русском языке, составляет первую важную меру правительства по отношению к народному образованию в С. 3. крае, которое легло краеугольным камнем всей дальнейшей системы образования в крае. Принятие этой меры состоялось в том же 1831 году, по Высочайшему повелению, последовавшему одновременно (в 4 день апреля) с тем, как постановлено было правилом вообще направлять общественное воспитание в С. 3. крае к сближению населения оного 3 природными русскими [арк. 23].

Вскоре вслед за этим последовало принятие другой важной меры по отношению к народному образованию к С. 3. крае касавшееся всех сословий края, именно - подчинение гимназий и училищ западных губерний действию общего устава учебных заведений в Империи, Височайше утвержденного в 28 день декабря 1828 года. Высочайшее повеление по сему предмету состоялось в 5 день июля 1834 года [арк. 24].

В следующем 1835 году стремление правительства относительно направления воспитания юношества всех вообще сословий С. 3. края выразилось еще определённее и решительнее. В этом году Мин-ство Нар. Просв. представило на Высочайшее благоусмотрение выработаный им общий план, согласно которому, по мнению Министерства, следовало вести общественное воспитание в западных губерниях по возстановлении в них учеб. заведений, приостановленых по случаю политических событий 1830 г. Выработанный Мин-ством Нар. Просв. план состоял в нижеследующем: 1. Возстановить в губерниях, возвращенных от Польши, общественные учеб. заведения в надлежащей связи и постепенности.
2. Так как направлением умственного образования будущих поколений преимущественно может быть приближено желаемое моральное и политическое слияние возвращенных от Польши губерний в общий состав государства, то означеные заведения следует возстановить и образовывать в духе русского, хотя большею частию и под наружностию прежних наименований. 3. Дабы не испугать с первого приёма умы, ослеплённые заблуждениями продолжительными и недавними и прежде всего овладеть доверенностью края, в учреждении училищ следовать твердому плану, снисходить на первый случай лишь к тем местным требованиям, кои неявно противны сему плану, а между тем вводить непреклонно, в духе и формах преподавания, тех главных условий, кои прямо относятся к имеющейся в виду цели. 4. По необходимости времени и по невозможности иметь немедленно достаточный запас людей, для полного преобразования учеб. системы требуемых, употреблять частию, как эпохою перехода, тех из прежних чиновников, кои не оглашены в предосудительном образе мыслей и в участии, притом в политических событиях. 5. Воспользоваться доверием высшего класса, дабы учредить возможное число Благородных Пансионов при гимназиях, которые, как отдельные заведения для постоянных пансионеров, преимущественно дают средства к ближайшему надзору и к точнейшему применению принятых начал. 6. Возстановляя с сими предосторожностями учебную систему в губерниях, возвращенных от Польши, перенести центр оной в Россию, приноровляя всю систему в должной постепенности к избранному центру [арк. 25-26].

Изложенный план общественного воспитания в западных губерниях, в 25 день марта 1835 года, удостоился Высочайшего одобрения, выразившегося в категорической и решительной форме: «Совершенно согласно с моими намерениями, строго держаться сего плана, ни в чем не послабляя и отнюдь не удаляясь» [арк. 26].

Приводя этот план в исполнение, правительство прежде всего обратило внимание на польский язык. Преподавание этого языка в учебных заведениях было признано решительно несовместимым с означеным планом и потому немедленно было воспрещено [арк. 26].

Таким образом преподавание польского языка, согласно Высочайшей воле, прекращено было, с 1838 г., во всех учеб. заведениях С. 3. края.

Этот запрет коснулся, впрочем, только правительственных учеб. заведений, в частных училищах польский язык по-прежнему преподавался. Но это отнюдь не означало, что частные училища могли находиться в сём отношении в 
особом положении. Оставление за ними права преподавания польского языка было, просто, мерою постепенною в приведении в исполнение изложенного выше плана. Навсегда же это право ни в каком случае не могло быть оставлено за частными училищами, так как, при таких условиях, усилив свою деятельность, они стали бы служить могущественным средством противодействия тем задачам, к которым стремились правительственные учеб. заведения, а это было бы совершенно несовместимо с видами правительства и поставило бы частные училища в резкое противоречие с основною целью их учреждения - «содействовать видам правительства» (Устав учеб. заведений, Высочайше утвержд. 8 декабря 1828 г., § 307). И действительно, по истечении пятнадцати лет со времени прекращения преподавания польского языка в правительственных учеб. заведениях, последовало воспрещение преподавания этого языка и во всех частных учеб. заведениях С. 3. края. Высочайшее повеление по сему предмету состоялось в 8 день февраля 1854 года [арк. 28].

С прекращением преподавания польского языка в учеб. заведениях, естественно и необходимо прекращалось право и домашних наставников и наставниц, домашних учителей и учительниц, а равно частных нач. учителей и учительниц, на преподавании этого языка в частных домах, так как эти звания учреждены «для содействия общим видам правительства по отношению к народному просвещению» (Положение о домашних наставниках и учителях, Височайше учрежденное 1 июля 1834 г. § 1) [арк. 28].

Таким образом с 1854 года, в пределах, подлежащих ведению правительства, преграждены были все пути для распространения польского языка среди учащегося юношества всех сословий С. 3. края [арк. 29-30].

Затем необходимо было принять меры к тому, чтобы устранить все другие способы вредного влияния на умы у воспитывающегося юношества, как например распостранение среди учащихся ложных понятий относительно исторического прошлого и современного политического положения края и т.п. [арк. 35].

Осуществляя столь важную меру по отношению к казенным учеб. заведениям, правительство не упускало из виду и частное обучение, которое, как объяснено выше, предназначено для содействия общим видам правительства по отношению к воспитанию юношества и, потому, в С. 3. крае всегда обращало на себя преимущественное его внимание. Правительство не могло, конечно устранить лишь лиц польского происхождения от обучения в частных домах, в каче- стве домашних наставников и наставниц, домашних учителей и учительниц и частных начальных учителей и учительниц, но оно могло устранить лиц польского происхождения от руководства воспитанием юношества в частных учебных заведениях. Это была мера первостепенной важности. Устраняя лиц польского происхождения от воспитания юношества в казенных учеб. заведениях, правительство обезпечивало согласно с его видами ход воспитания только по отношению к обучавшемуся юношеству мужского пола, так как в то время почти не было женских каз. учеб. заведений. Женское воспитание сосредотачивалось тогда почти исключительно в частных училищах, которые все содержались лицами польского происхождения. Между тем правильное, согласно с видами правительства, женское воспитание в С. 3. крае имело не только не меньшее, но даже еще большее значение, для нравственного и политического сближения края с Империей, так как польскими нравами, отчасти перешедшими и в нравы русских, за женщиною узаконено влияние, и притом большое, не только в жизни семейной, но и в общественной.

Правительство начало с того, что подчинило надзору учеб. начальства женские пансионы, состоявшие при р.к. женских монастырях и служившие главным рассадником самого крайнего религиозного и политического фанатизма. Высочайшее повеление по сему предмету последовало в 16 день июня 1835 года. Вместе с этим правительство приняло меры по устройству возможного числа каз. жен. учеб. заведений [арк. 39-40].

...преследуемая правительством цель по отношению к женскому воспитанию в крае тогда только может быть достигнута, когда это воспитание будет руководиться лицами природнорусскими, и что, по этому, женское воспитание в С. 3. крае вообще следует вверять только лицам русского происхождения, разрешая открытие и частных учеб. заведений только таким лицам. Так, как увидим ниже, смотрел на эту резолюцию и сам Государь и так понимало смысл её и Мин-ство Нар. Просв. Но на первых порах Минство Нар. Просв. затруднялось применением этой меры к частным жен. учеб. заведениям из опасения, что, по недостатку лиц русского происхождения, которые бы пожелали содержать частные жен. училища, и вообще по несочуствию поляков к училищам, содержимым природнорусским, получит сильное развитие домашнее воспитание, за которым трудно установить правильный контроль. Оставив пока частные жен. училища в руках лиц польского происхождения, 
правительство ограничилось на первых порах тем, что закрыло жен. училища, состоявшие при р.к. жен. монастырях, и открыло взамен их, на освободившиеся суммы, светские жен. училища. Эта мера приведена в исполнение согласно Высочайшему повелению 15 июня 1843 года [арк. 40-41].

В таком положении было дело до 1854 года. В этом году вновь выдвинулся на первый план вопрос о необходимости безотлагательного устранения лиц польского происхождения от руководительства частными жен. училищами [арк. 41].

При этом Г. Министр высказал заключение, что, в исполнение сообщенной ему Высочайшей воли о воспрещении уроженкам польским открывать женские пансионы и школы, он полагал бы предписать начальникам Учеб. Округов, негласно, к исполнению, следующие меры.

1. Означенную Высочайшую волю распространить и на смежную с Витебскою Могилевскую губернию и на губернии Виленского и Киевского Учебных Округов.

2. Дозволять впреть открывать там частные пансионы и школы для девиц преимущественно лицами русского происхождения, из польских же уроженок тем только, кои воспитаны в институтах, от правительства содержимых.

3. За существующими уже там женскими частными учеб. заведениями, которые состоят под управлением уроженок польских, не получивших образование в помянутых Институтах, усилить наблюдение и, с выбытием содержательниц оных по какому бы то ни было случаю, стараться заменять их другими лицами, имеющими право обучения или содержания учеб. заведений на основании предыдущего пункта [арк. 43].

Такое заключение Г. Министра Нар. Просв., по представлению Комитета Министров, Высочайше утверждено в 8 день июня 1854 года [арк. 43-44].

В таком решительном и строгом последовательном направлении развивались мероприятия правительства по отношению к устройству Нар. Образования в С. 3. крае до 1856 года. С этого же года начинается поворот в отношениях правительства к делу устройства народного образования в крае: возбуждается вопрос о допущении к воспитанию юношества в учеб. заведениях лиц польского происхождения и о восстановлении преподавания в сих заведениях польского языка. Оба эти вопросы вскоре и разрешены были, в законодательном порядке, в положительном смысле. Высочайшее соизволение на возобновление преподавания польского языка в учеб. заведениях состоялось, по докладу Г. Министра Нар. Просв., в 12 день ноября 1856 г., а Высочайшее соизволение на допущение лиц польского происхождения к воспитанию юношества в тех же заведениях - в январе 1857 г. [арк. 44].

Подобно тому, как прежде запретительные постановления, касавшиеся сначала правит. учеб. заведений, распространялось в последствии и на частные учеб. заведения, как назначеных для содействия общим видам правительства по отношению к воспитанию юношества, так теперь распросранена была на сии последнии заведения и отмена сказанных запретительных постановлений. Так, в 25 день июня 1857 г. последовало Высочайшее соизволение на дозволение лицам польского происхождения открывать частные училища [арк. 44-45].

Высочайшее соизволение на возобновление преподавания польского языка в частных учеб. заведениях последовало в 29 день марта 1858 года.

С возобновлением преподавания польского языка в учеб. заведениях, естественно получали право на преподавание этого языка в частных домах и домашние наставники и наставницы, домашние учителя и учительницы и частные начальные учителя и учительницы, так как права этих лиц по преподаванию тех или других предметов, по основной цели учреждения поименованных званий и по условиям приобретения права на обучение в частных домах, находяться, как объяснено выше, в самой тесной и непосредственной связи с правами учеб. заведений по преподаванию тех или других предметов [арк. 45-46].

Изучение польского языка детьми, принадлежащими к низшим сословиям, составляющим коренное население края, признано ненадежным и несовместимым с политическим воззрением, и потому означенное распоряжение, согласно Высочайшему повелению 20 апр. 1857 г., не было распространено на начальные (приходские) училища [арк. 46].

Такое же ограничение имело место и по отношению к частным училищам, именно Высочайшим повелением в 29 день марта 1858 г. разрешено было возобновить преподавание польского языка только в частные учеб. заведениях Виленской, Гродненской, Минской и Ковенской губерний; по отношению же к частным училищам в губерниях Витебской и Могилевской прежний запрет относительно польского языка остался во всей силе [арк. 47].

...С такими же - и даже еще большими 
ограничениями и предосторожностями разрешено было допускать лиц польского происхождения и к содержанию частных женских училищ, именно к этому разрешено было допускать так же только уроженок западных губерний и так же только при условии их полной благонадёжности. Но и при удовлетворении всем этим требованиям, допущение лиц польского происхождения к содержанию частных училищ не было постановлено общим правилом, в смысле признания за означеными лицами формального права на открытие таковых училищ, а было предоставлено, в каждом отдельном случае, усмотрению высших местных начальств учебного и гражданского. Кроме того, нужно заметить, что самое Высочайшее соизволение на допущение лиц польского происхождения к содержанию частных училищ последовало не в смысле обязательного постановления, а в смысле предоставления Минстру Нар. Просв. права разрешать означеным лицам содержать таковые училища, «если Министерство признает сие удобным и полезным» [арк. 49-50].

Итак, с 1856 года правительство стало, в деле народного образования, на путь уступок по отношению польскому обществу, в надежде, что преследуемая цель - прекращение вредного направления умов в крае может быть достигнута и без совершенного и безусловного устранения из учеб. заведений польских элементов, - одним лишь упрочением в них преимуществ начал русских [арк. 52-53].

Как мало было оснований для такой надежды, это доказали вскоре наступившие политические события в крае [арк. 53].

Гимназии, прогимназии и ... дворянские ... училища, которых было в крае весьма много, сделались постоянным средоточием польской пропаганды, образуя врагов России, так что даже православные, которые получили образование в сих гимназиях и училищах, с особенным чувством озлобления против России содействовали мятежникам [арк. 54].

...Всё это имело место в правительственных учеб. заведениях и в частных пансионах и училищах, находившихся под контролем правительства. Что же делалось в училищах, существующих без разрешения, и что происходило при обучении в частных домах, об этом и говорить нечего [арк. 54].

...Высочайше утвержденными 23 марта 1863 г. правилами для народных школ Виленского Учеб. Окр. точно и определенно постановлено, что в этих школах должен быть преподаваем только русский язык (§ 12), и что на том же языке должны быть преподаваемы и все предметы учеб. курса (§ 17) [арк. 61].

Таким образом с 1864 года правительство силою вещей вынуждено было возвратиться к прежней системе полного и безусловного устранения польского языка из народного обучения. С этих пор знание польского языка, так же как и прежде, могло поддерживаться только практическим путём или путём семейного обучения в полном значении этого слова. Всякое иное обучение польскому языку, как равно и обучение Закону Божию на этом языке, становилось обучением незаконным подлежащим преследованию [арк. 67].

Возвратившись к прежней системе в отношении польского языка, правительство силою тех же политических событий шестидесятых годов вынуждено было возвратиться к прежней системе в отношении лиц польского происхождения, желавших посвятить себя воспитанию юношества в учеб. заведениях. Правительство еще раз убедилось, что участие означеных лиц в общественном воспитании юношества неминуемо влечет за собою вредные брожение умов, и потому оно решило окончательно устранить этих лиц от великого дела воспитании юношества как в казённых, так и в частных учеб. заведениях [арк. 68].

Что касается допущения лиц польского происхождения к содержанию частных женских училищ, то от самого Мин-ства Нар. Просв. зависело прекратить действие этой меры, когда политические события шестидесятых годов обнаружили, что частные женские пансионы и школы, содержавшиеся в С. 3. крае лицами польского происхождения, сделались, как замечено выше, средоточием вредной язвы польской фанатической пропаганды между женщинами [арк. 70].

В виду происходивших С. 3. крае, в 1863 г. безпорядков, оно признало необходимым устранить влияние поляков на образование девиц, допуская открытие в крае только русских пансионов. С этой целью Мин-ство испросило в том же 1863 г. чрез Западный Комитет, Высочайшее соизволение (последовавшее в 24 день февраля 1863 года) на отпуск из казны особого кредита на поддержание означенных пансионов [арк. 70-71].

В следующем 1864 году судьба польских женских пансионов была окончательно решена [арк. 71].

Согласно таковой Высочайшей воле, все существовавшие в крае частные женские пансионы и школы были закрыты. На место их возникли школы русские, с содержательницами природно-русскими, при испытанной благонадёжности и лицам лютеранского исповедания. Вопрос о лицах, которым может быть дозволяемо 


\section{МАЛОВІДОМІ ДЖЕРЕЛА}

40

открывать частные пансионы и школы, было затем рассмотрено при обсуждении, в 1868 году, общего вопроса о необходимых изменениях и дополнениях действовавших в это время узаконений о частных училищах, и тогда было постановлено общим правилом, чтобы право содержания частных училищ в Империи было предоставляемо только «природно-русским» (см. Высочайше утвержденное 19 февраля 1868 года мнение Государственного Совета п. 5.) [арк. 72].

Таким образом лица польского происхождения вновь были устранены от влияния на ход воспитания юношества в учебных заведениях. Это была мера чрезвычайной важности: между тем как преобладание польского элемента в педагогическом составе учебных заведений обнаружилось деморализацией и вредным политическим характером учебных заведений, отозвавшееся гибелью для значительной части обучавшегося юношества, - при русских наставниках и преподавателях те же самые учебные заведения совершенно изменили свой характер и приняли направление, вполне соответствовавшее видам правительства и истинным пользам населения.

Но так изменилось, перейдя в русские руки, только общественное образование. Чтобы это образование могло приобрести действительную нравственную силу, необходимо было, чтобы по тому же направлению, или же по крайней мере, не в разрез с ним шло и развивалось и домашнее воспитание. [арк. 73].

Записка по вопросу о мерах $\kappa$ пресечению распространения недозволенного обучения $b$ северо-западном крае. Составлена $b$ ответ на возражения Г. Управляющего Мин-ством Юстиции, изложенные $b$ отзыве в Мин-ство Нар. Просв. от 14 июня 1886 года, за № 47296. Інститут рукопису Національної бібліотеки України імені В. І. Вернадського. Ф. 13 Канцелярія оберпрокурора Священного Синоду (1721-1917). Колекція архівних документів 677-1901. Спр. 3595. 107 арк. 